\title{
Chinese FDI Influence in the Capital Generation, Trade, and Inflation with the Perspective of Economic Development in Pakistan
}

\author{
Matiha Riaz, \\ Hongbing You, \\ Nanjing University of Science and Technology, Nanjing, P.R. China
}

Doi:10.19044/esj.2020.v16n22p254 URL:http://dx.doi.org/10.19044/esj.2020.v16n22p254

\begin{abstract}
The role of foreign direct investment has been essential in spurring growth by designing more opportunities in developing countries such as Pakistan. This paper focuses on predicting the effect of Chinese inward Foreign Direct Investment (FDI) with an exceptional and increasing role in Pakistan over the period from 2000 to 2018 . As a result, the study examines the relationship that exists among economic development, Chinese investment, trade openness, capital formation, and inflation using the Autoregressive Distributed Lag (ARDL) model. The results show a positive and significant relationship between Chinese investment in the development of Pakistan's economy by increasing capital and boosting the means of trade in global markets. It was supposed that Chinese investment can provide various opportunities such as firms with new markets, cheaper production facilities, and access to new technology, products, and skills if financed for productive purposes. It was recommended that policymakers should intervene through policy suggestions and implementation so that the economy would be able to take part in the race of becoming a global economy.
\end{abstract}

Keywords: Chinese Foreign Direct Investment, Capital Formation, Trade Openness, Economic Development, ARDL

\section{Introduction}

Foreign investment can be considered as the investment and equity flows in the developing economies. It refers to the sum of Capital's equity by reinvesting the earnings in the market. However, foreign direct investment (FDI) is the type of investment that takes place at the international level, has a relationship with the economy, has full control over the management, and is associated with other economy. The determinant of the direct investment 
relationship is the ownership of 10 percent, or more than it, in the shares of voting stocks for the individual existence of the relationship.

The foreign direct investment proved to be a major contributor to growth due to its significant contribution to capital formation and technological innovation (Kukaj \& Ahmeti, 2016). FDI continued to be a major issue and most of the scholars provided evidence that FDI is not only the general economic development but also a signal for the maturity of recipient countries. Therefore, it can be used as a tool for structuring and attaining sustainable development and could also attract more FDI by establishing a new business (Jibir \& Abdu, 2017). Recently, foreign investment is a critical issue in the emerging markets because it has not only become the initial targets of foreign investment, but it also played a vital role as investors likewise China, Brazil, and India (Carvalho, Duysters \& Costa, 2010; Hill \& Jongwanich, 2011). The interest of foreign investors is determined majorly by economic development, the location of the host country, and the advantages associated with it. The inward FDI makes significant contribution to a country by investing in capital formation, especially Chinese OFDI, which is positively related to these contributions (Gao et al., 2013).

Based on a dissimilar concept of international investment theory, a unique pattern was seen where Chinese foreign direct investment is highly located, including the nations having low standard of institutional quality. Hence, they were regarded as the puzzle of China's investment institutional risk preference (Yang et al., 2017). Typical theories of an investment highlighted that Foreign investment would be more effective if it is allocated to nations with a standard institutional quality. Many kinds of literature explained that the low quality of institutions in the host nations leads to protection of invalid asset which removes the risk and also help to upgrade the weak institutional environment (Blonigen, 2005). The aforementioned circumstances could be the hurdle in FDI inflows by raising the risk that emerged with the cost of an investment. Another aspect of weak institutional quality is the invisible tax burden that reduces the output from the investment (Daude \& Stein, 2008). Therefore, host countries having a strong regulatory and the quality of institutional reforms are basic requirements for the inflows of FDI. A recent study found that some market factors were involved and have helped in determining the area of Chinese foreign direct investment flows. Stable institutional quality plays an important role in economic development. Alfero et al. (2014) argued that against the framework of the flow of capital at a global level, from the poor to rich nations, the direction of foreign investment should be from rich to poor countries with higher returns. Stein and Daude (2001) and Benassy-Quere et al. (2007) stated that FDI flows and the institution could be misconducted if it is without the concern of the economic 
development of the recipient country. Limited attention has been received by outward foreign direct investment that leads to enhanced innovative performances (Piperopoulos et al., 2018). According to the World Investment Report (2016), the developing countries have a total stock of 9.9\% FDI in 2002 and a total of $21.1 \%$ in 2015 (UNCTAD, 2016). China Outward FDI was $\$ 27.8$ billion and $\$ 1.01$ trillion in 2000 and 2015, respectively. In Asia, China remained the third highest country in FDI flows, i.e., it has an $8.6 \%$ rate compared to the world's total flows of FDI.

Figure 1. Comparison of total FDI inflows and Chinese FDI inflows in Pakistan

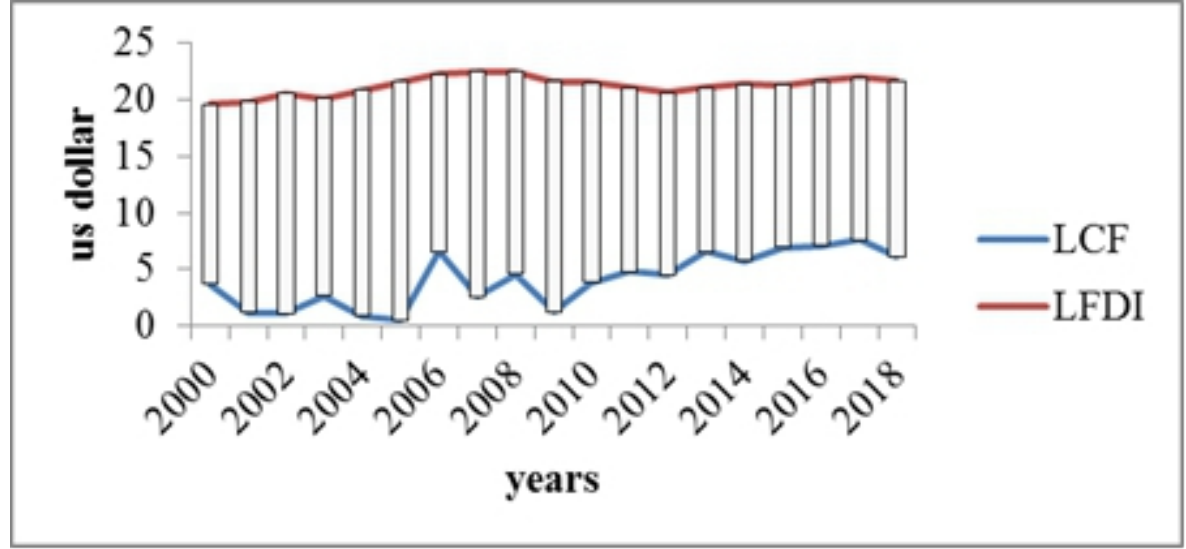

Sustainable development could be achieved through strategic planning that establishes priorities in the territory or sector, which involves a new capital in such a way that leads to development (Krasniqi \& Krasniqi, 2015). The sector of a territory involves the large range of economic activities in which transportation, financial services, and the information about trade and technology exists. In 2008, almost half of the business services have used secondary portions (Dar et al., 2016). Advanced economies help to raise the $48 \%$ service intensity for electronic products and $\$ 268$ billion raised in the sector. Despite the massive fluctuations, FDI maintains a $2 \%$ growth rate in all sectors, while it was 4\% in developing countries in 2012 (WDI). However, these growth patterns indicate improvement in foreign capital and domestic capabilities in the emerging nation (Agmon \& Hirsch, 1979).

Effective trade and investment is a fundamental factor for sustainable economic development (Gusarova, 2019). FDI plays an important role in carrying out global strategies, and it can also help to upgrade the country's export level and patent licenses. The International Monetary Fund (IMF) is monitoring the reduction in investment in developing countries that mitigate their economic as well as social consequences (Tolentino, 2010). Many macroeconomic factors often lead to a decline in FDI inflows, a backlash against multilateral trade liberalization, which includes the high rate of domestic trade. The interest rate would be the vulnerability of structural 
economics in which FDI matters and might mitigate multilateral trade liberalization of FDI flows (Gnangnon, 2017).

This study has important objectives such as Chinese foreign direct investment allows the technology transfer, especially in the form of new varieties of capital inputs that cannot be achieved by growing economies on their own. Furthermore, the purpose of this estimation is to find the integration of the economy to the global economy. The economic factor such as the degree of openness of the recipient country, its absorptive capacity, and its growth prospects are highlighted. Lastly, different policy recommendations by policymakers should be made to attract foreign direct investment and increase their effectiveness.

The paper is divided into five (5) parts. The first part consisted of an introduction highlighting the history and importance of foreign direct investment. The second part is based on a review of the literature to support the study. The third part focuses on the estimation process and its steps are defined. The fourth part supports the outcomes of estimation while the last part involves discussion and policy recommendations.

\section{Review of Literature}

China is one of the major countries in the world that supports other emerging nations for their economic development. Several studies estimated the effect of FDI on the countries growth level. Hence, the summary of the literature is given below:

Table 1. Summary of literature reviews

\begin{tabular}{|c|c|c|c|c|}
\hline Author & Period of study & Country/region & Methodology & Results \\
\hline $\begin{array}{l}\text { Fan et al. } \\
(2017)\end{array}$ & 2001-2012 & China & $\begin{array}{l}\text { Regression tests } \\
\text { and placebo test }\end{array}$ & $\begin{array}{l}\text { FDI had stronger effects. } \\
\text { For more productive firms } \\
\text { having foreign ownership and } \\
\text { labor-intensive sectors. }\end{array}$ \\
\hline $\begin{array}{l}\text { Gusarova } \\
(2019)\end{array}$ & $\begin{array}{l}\text { Over the next } \\
50 \text { years }\end{array}$ & BRICS & $\begin{array}{l}\text { Multiple regression } \\
\text { analysis }\end{array}$ & $\begin{array}{l}\text { Trade and investment from china } \\
\text { exerted a very strong impact on } \\
\text { the development of emerging } \\
\text { economies. }\end{array}$ \\
\hline $\begin{array}{l}\text { Shahbaz et } \\
\text { al. (2018) }\end{array}$ & $1955-2016$ & France & $\begin{array}{l}\text { SOR unit root and a } \\
\text { bootstrapping } \\
\text { bounds test }\end{array}$ & $\begin{array}{l}\text { FDI had a positive effect, while } \\
\text { R\&D had a negative impact. } \\
\text { Further financial development } \\
\text { had a crucial role in terms of } \\
\text { stability. }\end{array}$ \\
\hline $\begin{array}{l}\text { Gao et al. } \\
(2013)\end{array}$ & $1979-2009$ & China & $\begin{array}{l}\text { VECM approach } \\
\text { and GMM approach }\end{array}$ & $\begin{array}{l}\text { Chinese FDI was driven by the } \\
\text { domestic economic development } \\
\text { and students, and scholar } \\
\text { promoted OFDI. }\end{array}$ \\
\hline $\begin{array}{l}\text { Yang et al. } \\
(2013)\end{array}$ & $1987-2000$ & China,Taiwan & $\begin{array}{lr}\text { Propensity } & \text { score } \\
\text { matching } & \text { method } \\
\text { and meta } & \text { frontier } \\
\text { framework } & \\
\end{array}$ & $\begin{array}{l}\text { Technical efficiencies increased } \\
\text { with an increase in FDI } \\
\text { activities. }\end{array}$ \\
\hline
\end{tabular}




\begin{tabular}{|c|c|c|c|c|}
\hline $\begin{array}{l}\text { Yang et al. } \\
(2017)\end{array}$ & $2003-2012$ & $\begin{array}{l}\text { Investment in } 132 \\
\text { economies }\end{array}$ & $\begin{array}{l}\text { Multiple regression } \\
\text { and variance } \\
\text { inflation factor }\end{array}$ & $\begin{array}{l}\text { Chinese multinationals were } \\
\text { prone to locate an investment } \\
\text { with high institutional quality } \\
\text { and less economic development. }\end{array}$ \\
\hline $\begin{array}{l}\text { Gnangnon } \\
(2017)\end{array}$ & $1998-2013$ & 112 economies & $\begin{array}{l}\text { Two steps GMM } \\
\text { estimation }\end{array}$ & $\begin{array}{l}\text { The lower level of development } \\
\text { leads to a higher rate of trade on } \\
\text { FDI outflow. Also, higher } \\
\text { structural } \\
\text { vulnerability discouraged FDI. }\end{array}$ \\
\hline $\begin{array}{l}\text { Mourao } \\
(2017)\end{array}$ & $2003-2010$ & $\begin{array}{ll}48 & \text { African } \\
\text { countries } & \end{array}$ & $\begin{array}{l}\text { Efficiency score and } \\
\text { maximum } \\
\text { likelihood } \\
\text { estimation. }\end{array}$ & $\begin{array}{l}\text { It was concluded that countries } \\
\text { having large population and } \\
\text { forest were preferred for the } \\
\text { Chinese foreign direct } \\
\text { investment }\end{array}$ \\
\hline $\begin{array}{l}\text { Latorre et } \\
\text { al. (2018) }\end{array}$ & 2004-2016 & $\begin{array}{l}\text { China-US and EU } \\
27\end{array}$ & $\begin{array}{l}\text { A computable } \\
\text { general equilibrium } \\
\text { model }\end{array}$ & $\begin{array}{l}\text { It was suggested that foreign } \\
\text { multinationals in services tended } \\
\text { to increase FDI from China, but } \\
\text { the impact is smaller than other } \\
\text { studies. }\end{array}$ \\
\hline $\begin{array}{l}\text { Adonsou \& } \\
\text { Lin (2018) }\end{array}$ & 2004-2011 & $\begin{array}{l}36 \\
\text { countries }\end{array}$ & $\begin{array}{l}\text { Fixed effect and } \\
\text { instrumental } \\
\text { variable approach }\end{array}$ & $\begin{array}{l}\text { Chinese FDI improved income } \\
\text { in Africa, which has more impact } \\
\text { than U.S and German } \\
\text { investments. }\end{array}$ \\
\hline $\begin{array}{l}\text { Habyarima } \\
\text { na \& } \\
\text { Opoku } \\
(2018)\end{array}$ & $2000-2015$ & Africa & $\begin{array}{l}\text { Instrumental } \\
\text { variable-GMM }\end{array}$ & $\begin{array}{l}\text { The Chinese engagement in the } \\
\text { trade leads to positive and } \\
\text { negative impacts on GD and } \\
\text { technological progress. Further } \\
\text { increased capital caused } \\
\text { stagnation in technological } \\
\text { progress. }\end{array}$ \\
\hline $\begin{array}{l}\text { Dar et al. } \\
(2018)\end{array}$ & $1997-2013$ & Pakistan & $\begin{array}{lr}\text { VECM } & \text { panel } \\
\text { cointegration } & \text { and } \\
\text { PCA } & \end{array}$ & $\begin{array}{l}\text { The estimation showed both long } \\
\text { and short estimation but were } \\
\text { unable to show sector-wise } \\
\text { relation. Moreover, FDI showed } \\
\text { short-run relation with GDP. }\end{array}$ \\
\hline $\begin{array}{l}\text { Oxelheim } \\
\& \quad \text { Ghauri } \\
(2008)\end{array}$ & $1980-2004$ & EU and China & $\begin{array}{l}\text { Comparison over } \\
\text { time }\end{array}$ & $\begin{array}{l}\text { The results described the } \\
\text { deviation from the long-run } \\
\text { relation. Further problem of } \\
\text { understanding the factors of } \\
\text { attracting investment were seen. }\end{array}$ \\
\hline $\begin{array}{ll}\text { Sun } & \& \\
\text { Anwar } & \\
(2019) & \end{array}$ & $2000-2016$ & China & $\begin{array}{l}\text { Exact matching } \\
\text { technique }\end{array}$ & $\begin{array}{l}\text { The industries used more } R \& D \\
\text { from FDI which had greater } \\
\text { returns, while industries that } \\
\text { didn't use } R \& D \text { had a positive } \\
\text { and sizable impact on the } \\
\text { economy. }\end{array}$ \\
\hline $\begin{array}{l}\text { Shah et al. } \\
(2019)\end{array}$ & $1980-2012$ & Pakistan & $\begin{array}{l}\text { ARDL } \\
\text { cointegration } \\
\text { technique }\end{array}$ & $\begin{array}{l}\text { In Pakistan, FDI in the primary } \\
\text { sector impacted insignificantly } \\
\text { on domestic investment and } \\
\text { concluded that domestic } \\
\text { investment was necessary to } \\
\text { attract FDI Inflows. }\end{array}$ \\
\hline $\begin{array}{l}\text { Anderson et } \\
\text { al. }(2019)\end{array}$ & $\begin{array}{l}\text { Comparison in } \\
2011\end{array}$ & 89 countries & $\begin{array}{l}\text { General equilibrium } \\
\text { model }\end{array}$ & $\begin{array}{l}\text { World welfare loss was seen } \\
\text { from FDI removal to poorer } \\
\text { countries and had a negative } \\
\text { impact on world trade. }\end{array}$ \\
\hline
\end{tabular}




\begin{tabular}{|c|c|c|c|c|}
\hline $\begin{array}{l}\text { Economou } \\
(2019)\end{array}$ & $1996-2017$ & $\begin{array}{l}4 \text { South European } \\
\text { economies }\end{array}$ & $\begin{array}{ll}\text { Random } & \text { effect } \\
\text { panel model }\end{array}$ & $\begin{array}{l}\text { The positive influence of market } \\
\text { size, capital formation, and } \\
\text { negative association of cost was } \\
\text { seen on FDI inflows }\end{array}$ \\
\hline $\begin{array}{l}\text { Piteli et al. } \\
(2019)\end{array}$ & $1995-2009$ & $\begin{array}{l}28 \text { emerging } \\
\text { economies }\end{array}$ & OLS and FGLS & $\begin{array}{l}\text { It was shown that masculinity } \\
\text { and power distance increased the } \\
\text { economic effects of inflows. }\end{array}$ \\
\hline $\begin{array}{l}\text { Kayalvizhi } \\
\& \\
\text { Thenmozhi } \\
(2017)\end{array}$ & 1996-2014 & $\begin{array}{l}22 \text { emerging } \\
\text { economies }\end{array}$ & $\begin{array}{l}\text { Panel model with } \\
\text { fixed effect. }\end{array}$ & $\begin{array}{l}\text { The results suggested that due to } \\
\text { an increase in technological } \\
\text { innovation, capacity FDI also } \\
\text { increased. Furthermore, culture } \\
\text { and governance attract inward } \\
\text { FDI. }\end{array}$ \\
\hline Shi (2019) & 2003-2013 & China and the U.S & Shocks evaluation & $\begin{array}{l}\text { Short-run fluctuation in FDI } \\
\text { caused a loss in the business } \\
\text { cycle with monetary shock. } \\
\text { Furthermore, it had little effect } \\
\text { on welfare with productivity } \\
\text { shocks. }\end{array}$ \\
\hline
\end{tabular}

\section{Materials and Method}

The developing countries mostly depend on the investment from the foreign countries to boost their development. Various economic sectors could use this investment received from foreign countries such as China. The purpose of this study is to check the impact of Chinese FDI in Pakistan on capital formation, inflation, trade openness, and country growth level. This study utilized the data from the period 2000 to 2018 from World Bank. This study used the Cointegration Model to check the long-run effect of the Chinese Foreign Direct Investment (CFDI) on the economic growth of Pakistan.

$$
L G D P C=\beta 1 L n G C F+\beta 2 L n C P I+\beta 3 L n C F D I+\beta 4 L n T O+\mu i \rightarrow(1)
$$

Where L represents the natural $\log$, GDPc is the per capita economic growth, GCF is the gross capital formation in the country, CPI is the proxy of inflation known as the consumer price index, CFDI is the Chinese foreign direct investment, LnTO represents the degree of trade openness, and $\mu i$ describes the stochastic error term.

Table 2. Description of variables

\begin{tabular}{|c|c|c|c|}
\hline Variables & Abbreviations & Unit & Source \\
\hline GDP per capita & LGDP & Current US \$ & WDI \\
\hline $\begin{array}{l}\text { Gross Capital } \\
\text { Formation }\end{array}$ & LnGCF & Current US \$ & WDI \\
\hline $\begin{array}{l}\text { Consumer Price } \\
\text { Index }\end{array}$ & LnCPI & $2010=100$ & WDI \\
\hline $\begin{array}{l}\text { Chinese Foreign } \\
\text { Direct Investment }\end{array}$ & LnCFDI & Million \$ & OECD statistics / paper \\
\hline Trade Openness & LnTO & Current US \$ & Import+export/GDP \\
\hline
\end{tabular}

Note: Ln describes the natural log of variables 


\section{Unit Root Test}

The major estimation concern is to check the stationary level of the given data. Due to spurious estimation, the data had a lot of problems in time series (t). This study used the Augmented Dickey-Fuller (ADF) test to remove the existence of unit root (Dickey \& Fuller, 1981).

$\Delta y t=\alpha+\beta t+\gamma_{-}(y t-1)+\delta_{-} 1 \Delta_{-}(y t-1)+\cdots+\delta_{-}(\rho-1) \Delta_{-}(y t-p+1)+\mu t$ In $\rightarrow(2)$, $\alpha$ is showing constant while $\beta$ is a coefficient, and the order of lag of Autoregressive process is $\delta$.

\section{Cointegration Test}

The Cointegration test approach was used to check the long-run relationship among variables. F-pieties are compared with the critical values of I (0) and I (1), which are upper and lower boundaries. If the calculated value of $\mathrm{F}$ statistics exceeds the upper boundary, then it shows the presence of cointegration and the long term and short term effects are measured. Several diagnostic tests are also performed for complement bounds testing.

\section{Diagnostic Testing}

This study uses the Breusch — Godfrey Serial Correlation LM Test to resolve the problem of autocorrelation. Also, this study uses the BreuschPagan Godfrey test to tackle the problem of heteroskedasticity, which shows whether autocorrelation and heteroskedasticity are present in the model.

Ho: autocorrelation present between series

H1: no autocorrelation exists between series

\section{Autoregressive Distributed Lag (ARDL) Model}

The long-run relationship can be measured by the ARDL approach (Pesaran et al., 2001). ARDL has advantages over other methodologies such as Vector Error Correction Model (VECM) because it can be used with $\mathrm{I}(0)$ and I(1) integrations. The ARDL method also supports the small sample size and flexibility of different lag lengths. Thus, long-run estimates will be calculated as follows:

$$
\left.Y i t=\sum_{j=1}^{p} \lambda i j Y i_{s_{t-j}}+\sum_{j=0}^{q} \delta i j X i_{s_{t-j}}+\mu t+\varepsilon_{i t}\right) \rightarrow(3)
$$

Where $\mathrm{i}$ represents the number of cross-sections, $\mathrm{i}=1,2,3, \ldots \ldots \ldots \ldots \mathrm{N}$ and $\mathrm{t}$ represents time dimension $\mathrm{t}=1,2,3 \ldots \ldots \ldots \ldots . \mathrm{T}$. $\lambda \mathrm{ij}$ is scalar and Xit represents a vector of regressors. $\mu$ i represents the group-specific effect. 


\section{Results}

Table 3. Result of Unit Root Test

\begin{tabular}{|c|c|c|c|c|c|c|c|c|}
\hline \multicolumn{9}{|c|}{ ADF test for unit root } \\
\hline \multirow[b]{2}{*}{ Variables } & \multicolumn{4}{|c|}{ At level } & \multicolumn{3}{|c|}{ At first difference } & \multirow[b]{2}{*}{ and } \\
\hline & Intercept & & $\begin{array}{l}\text { Intercep } \\
\text { Trend }\end{array}$ & & Intercep & & $\begin{array}{l}\text { Intercept } \\
\text { Trend }\end{array}$ & \\
\hline LnGDPc & -0.7628 & 0.8055 & -1.3127 & 0.8508 & -3.5074 & 0.0210 & -3.6326 & $0.0572 *$ \\
\hline LnGCF & -0.6136 & 0.8443 & -3.2956 & 0.1024 & -2.8992 & $0.0662 *$ & -2.8781 & 0.1924 \\
\hline LnCPI & -1.1152 & 0.6842 & -2.4292 & 0.3521 & -4.8007 & 0.0041 & -9.6312 & $0.0001 *$ \\
\hline LnCFDI & -0.9731 & 0.7378 & -5.6710 & $0.0013 *$ & -7.8609 & 0.0000 & -7.5502 & $0.0001 *$ \\
\hline LnTO & -1.4441 & 0.5378 & -1.4029 & 0.8240 & -3.6569 & 0.0157 & -3.9067 & $0.0355^{*}$ \\
\hline
\end{tabular}

Note: $* * *, * * *$ denotes the significance at $1 \%, 5 \%$ and $10 \%$, respectively.

In Table 3, the results of the ADF test are given. This was according to the estimation and the variables that are stationary at the level $\mathrm{I}(0)$ and at the first difference I(1). The results show that variables such as LnGDPC, LnGCF, LnCPI, and LnTO are integrated at the first difference, while LnCFDI is integrated at the level. Therefore, the stationary of variables suggested that the ARDL test best fits the data.

Table 4. Results of Bounds Test

Test Statistic Value K

F-statistic 5.2574604

Critical Value Bounds

Significance I0 Bound I1 Bound

\begin{tabular}{lll}
\hline $10 \%$ & 2.45 & 3.52 \\
$5 \%$ & 2.86 & 4.01 \\
$2.5 \%$ & 3.25 & 4.49 \\
$1 \%$ & 3.74 & 5.06
\end{tabular}

After estimating the stationary of variables, the next step is to estimate the cointegration relation among variables. For this purpose, ARDL based Wald Test which examines the presence of long-run association is investigated by the use of the test, and the ARDL bound test results are shown in Table 4. It was seen that all the critical values of $\mathrm{I}(0)$ and $\mathrm{I}(1)$ are higher than the value of F-statistics. Therefore, the null hypothesis of no cointegration is not acceptable. This implies that LnGDPC, LnGCF, LnCPI, LnCFDI, and LnTO exhibits long-run association.

Table 5. Long Run Coefficients

\begin{tabular}{lllll}
\hline Variable & Coefficient & Std. Error & t-Statistic & Prob. \\
\hline LCFDI & 0.023822 & 0.008801 & 2.706607 & $0.0303^{* *}$ \\
LCPI & -0.361040 & 0.060801 & 5.938035 & $0.0006^{*}$ \\
LGCF & 0.135555 & 0.107897 & 1.256333 & 0.2493 \\
LTO & 0.176801 & 0.121435 & 1.455924 & 0.1888 \\
C & -2.470705 & 1.281507 & -1.927968 & $0.0952^{* * *}$ \\
\hline
\end{tabular}


Once it is confirmed that, both at the level $\mathrm{I}(0)$ and at the first difference I(1), all the variables are integrated, progress is made toward the ARDL approach. The advantages of ARDL show that it estimates both longrun association and short-run association at the same time. To estimate the actual long-run association among variables in the model proposed, the following equation is estimated through the ARDL approach.

$L G D P C=0.1355 \operatorname{LnGCF}-0.3610 \operatorname{LnCPI}+0.0238 \operatorname{LnCFDI}+0.1768 \operatorname{LnTO}-2.4707 \rightarrow$ (4)

In Table 5, the results are given which is the summary of equation 4 and are in line with the theories. According to the results, $1 \%$ increase in Chinese foreign direct investment increases the economic growth by $0.02 \%$ folds. This means that the economic growth of the country can boost up by increasing China's investment. Economic growth will increase by $0.36 \%$ by the $1 \%$ decrease in the consumer price index, and this is significant. Thus, according to results, $1 \%$ increase in gross capital formation can change the economic growth by $0.13 \%$. Consequently, increasing capital in the country will lead to increase in the economic growth. For the competitive development, investment is required in the different sectors such as exports and infrastructure. Also, export and foreign investment could have significant effects in two ways, i.e., either positive or negative (Shaqiri, 2017). However, this study supports a positive influence. The coefficient of capital formation is positive but insignificant. Another variable at $0.17 \%$ will increase by trade openness if the coefficient is positive, but insignificant as well.

Table 6. Short Run Coefficients

\begin{tabular}{lllll}
\hline Variables & Coefficient & Std. Error & t- statistics & Prob. \\
\hline D(LGDPPC(-1)) & 0.285935 & 0.205434 & 1.391861 & 0.2066 \\
D(LCFDI) & 0.018904 & 0.007530 & 2.510425 & 0.0404 \\
D(LCPI) & 1.088206 & 0.584370 & 1.862189 & 0.1049 \\
D(LGCF) & 0.189171 & 0.171525 & 1.102877 & 0.3065 \\
D(LTO) & 0.096126 & 0.130889 & 0.734412 & 0.4866 \\
CointEq(-1) & -1.395536 & 0.319315 & -4.370403 & 0.0033 \\
\hline
\end{tabular}

The short-run estimates are given in Table 6 which predicts that all the variables are positively impacting the economic growth. Chinese Foreign Direct Investment is positively affecting the GDP by $0.01 \%$, while the result of CPI is different from the long-run. The CPI is positively affected with $1.08 \%$ but is insignificant. Similarly, the GDP of $0.18 \%$ will increase by increasing the gross capital formation of $1 \%$. Lastly, trade openness has a positive effect, i.e., a $1 \%$ increase in trade openness will increase the GDP by $0.09 \%$. 


\section{Diagnostic Results}

Table 7. Results of Breusch- Godfrey Serial Correlation LM Test
F - statistic
0.348538
Prob. $\mathrm{F}(2,5)$
0.7216
Obs $* \mathrm{R}-$ squared
2.080066
Prob. Chi-Square(2)
0.3534

Table 8. Results of Heteroskedasticity Test: Breusch-Pagan-Godfrey

\begin{tabular}{llll}
\hline F-statistic & 0.932056 & Prob. F(9,7) & 0.5501 \\
Obs*R-squared & 9.266953 & Prob. Chi-Square(9) & 0.4130 \\
Scaled explained SS & 0.922100 & Prob. Chi-Square(9) & 0.9996 \\
\hline
\end{tabular}

Diagnostic checking is the last step of the ARDL approach to examine the prediction of the model used in the study. This study employed the LM test for serial correlation and Breusch-Pagan-Godfrey test for heteroskedasticity. The results of serial correlation and heteroskedasticity are given in Tables 7 and 8. The results show that F-statistic values are not significant, indicating that the variable has no autocorrelation. Hence, this rejects the null hypothesis of autocorrelation. Furthermore, the figures of CUSUM and CUSUMSQ show the positive trend of variables with economic growth as the lines of both CUSUM and CUSUMSQ lies under critical range.

\section{Stability Results of CUSUM and CUSUM of Squares}

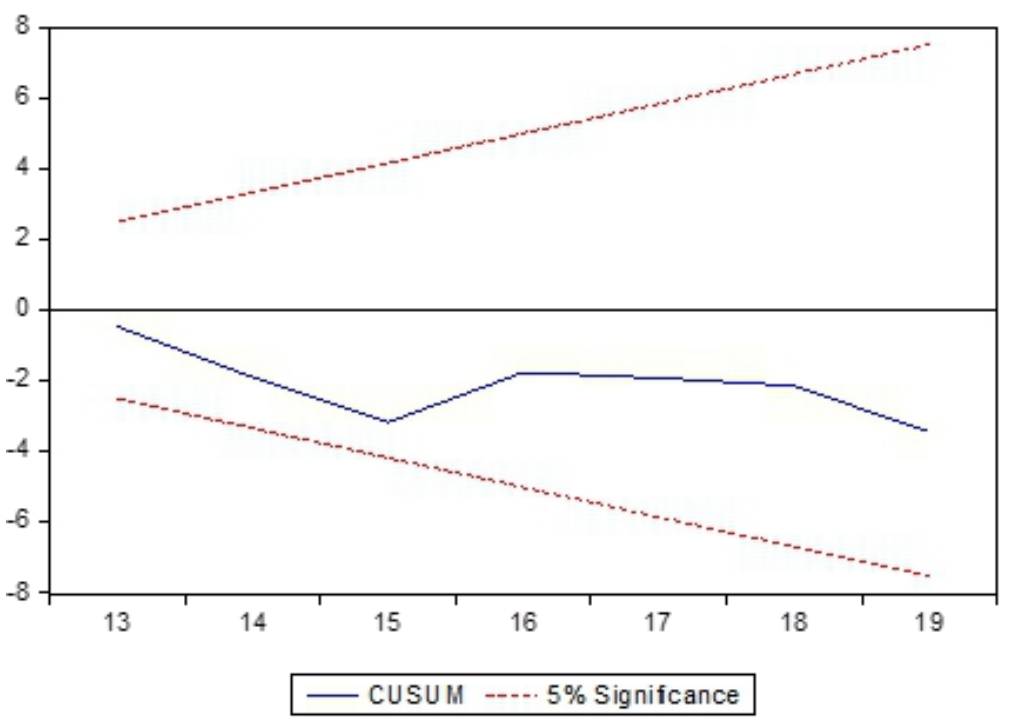




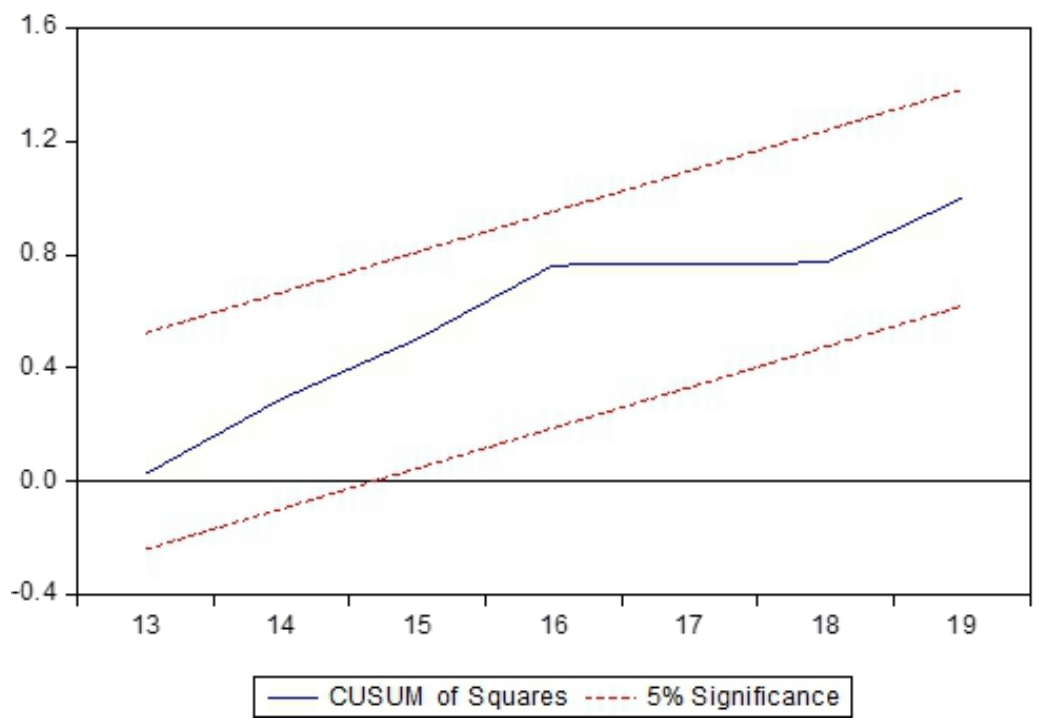

\section{Discussion}

This study proposed a perspective view of the support for Pakistan in the form of Chinese foreign direct investment. The traditional indicators of economic growth focus on the impact of overall aid received by a recipient country, which does not provide insight to individual donor aid to the recipient. To estimate the impact of Chinese foreign direct investment in the grooming of Pakistan's economic development, while considering the other main determinants of growth such as capital formation, inflation and trade openness, this study is constructed. The period of the data is from 2000-2018, and it was collected from the World Bank indicator. After the application of time series multiple tests, the cointegration results revealed the need to apply ARDL bound testing approach for long-run estimation. The stability tests define the clear image of the fluctuations of variables in the long-run.

According to the ARDL bound testing approach, short-run results reveal the positive impact of capital formation, Chinese foreign direct investment, trade openness as well as the consumer price index. According to Nyangarika et al. (2019) and Mahmoud (2015), moderate inflation might encourage productivity and output level. On the other hand, the consumer price index has a negative impact on the economic development of Pakistan and is in line with the theories stated by Rehman et al. (2019) and Lye et al. (2019). The Chinese foreign direct investment has a positive and enormous effect on the economic development of Pakistan as China is one of the main investors in Pakistan. Here, there are a great number of opportunities that can improve the living standards of people as suggested by Stanojevic (2019). Similarly, other control variables in this study such as trade openness and capital formation also play positive roles in boosting the economic 
development in Pakistan (Mukhtar et al., 2019; Nizam et al., 2020; Rahman \& Ahman, 2019; Awan et al., 2020).

\section{Conclusion}

Pakistan is one of the emerging countries that depend on the investment received from foreign countries. The biggest portion of foreign investment comes from China. In the year 2000, the portion of Chinese FDI was so small but it increased eventually. The investment in Pakistan by China reached $\$ 1.37$ billion in 2010, but flow in 2011 and 2012 was meager. The major portion of this investment is utilized in the power sector, infrastructure, telecommunication, mining, and trade. Furthermore, according to Zefi and Pasholli (2011), the foreign direct investment would have a positive effect on economic growth if diffused with technological innovation as well as developing the financial system of the host country. Thus, financial development and technological innovation are the pre-conditions for growth. Attracting more investment from China would strengthen Pakistan's economy and will upgrade the tradable activities. Pakistan is continuously promoting investment policies to attract investment overseas. It facilitates investors through profit, according to the foreign private investment Act 1976 dividends in capital gains in terms of legal protection. However, through profit, the existing literature on FDI in Pakistan is not supportive. Several studies of Iqbal, Shaikh and Shar (2010), Ghazali (2010), and Ahmed, Hayat, Luqman and Ullah (2012) revealed the impact of FDI on Pakistan's economic growth, trade openness, GDP per capita, and inflation. Also, the data of all variables are taken from World Bank spanning from 2000-2018. ARDL was used to find out the long-run estimation.

The results proposed that by investing in capital formation, the development of a country will be boosted as new opportunities are found. The new opportunities will create more employment in the country that strengthens the living standards of the society and eventually reduce inflation. By investing in the productive sectors of the economy, new boundaries will be opened to export the domestic commodities in the global market. Hence, Chinese investment could boost the economic growth of Pakistan.

\section{Policy Recommendations}

According to the above-explained relationship between variables, this study suggested the following policy recommendations:

- International experience and Pakistan's experience suggests that Chinese investment benefits and magnify the private and public efforts and boost industrial capabilities. Equipment can be modernized by investing in capital formation and raising quality and productivity as well as meeting up with the environmental limitations. 
- Investment in research and development will promote diversification and the evaluation process might forecast the future benefits through research and development in specific fields of the line.

- Policymakers should enhance the benefits of Chinese FDI by focusing on the ideas, and by also maintaining the inflation level of growth in Pakistan.

\section{Limitations of the Study}

Due to several factors, there are certain limitations in this study. Firstly, this study explored the effects of Chinese FDI on the development of Pakistan economy. Therefore, future research can be conducted by specifying other countries. The second limitation is the sample size, which was from 2000-2018. Although it is sufficient to carry the examination, it can be expanded further. Thirdly, this research is carried out only on limited variables of the author's interest. Thus, the impact of Chinese foreign direct investment can be examined on technological innovation, environmental problems, and in the industrial sector.

\section{References:}

1. Agmon, T. \& Hirsch, S. (1979). Multinational corporations and the developing economics: potential

2. Aizenman, J., Jinjarak, Y., \& Zheng, H. (2018). Chinese outwards mercantilism: The art and practice of bundling. Journal of International Money and Finance, 86, 31-49.

3. Albulescu, C. T. \& Ionescu, A. M. (2018). The long-run impact of monetary policy uncertainty and banking stability on inward FDI in EU countries. Research in International Business and Finance, 45, 7281.

4. Alfaro, L., Kalemli-Ozcan, S., \& Volosovych, V. (2014). Sovereigns, upstream capital flows, and global imbalances. Journal of the European Economic Association, 12(5), 1240-1284.

5. Anderson, J. E., Larch, M., \& Yotov, Y. V. (2019). Trade and investment in the global economy: A multi-country dynamic analysis. European Economic Review, 120, 103311.

6. Awan, A. G. \& Qasim, H. (2020). The impact of external debt on Economic Growth of Pakistan. Global Journal of Management, Social Science and Humanities, 6(1), 30-61.

7. Barba Navaretti, G. \& Venables, A. J. (2004). Multinational Firms in the World Economy. Princeton: Princeton University Press.

8. Bénassy-Quéré, A., Coupet, M., \& Mayer, T. (2007). Institutional determinants of foreign direct investment. The World Economy, 30(5), 764-782. 
9. Blonigen, B. A. (2005). A review of the empirical literature on FDI determinants. Atlantic Economic Journal, 33(4), 383-403.

10. Cai, H., Boateng, A., \& Guney, Y. (2019). Host country institutions and firm-level R\&D influences: An analysis of European Union FDI in China. Research in International Business and Finance, 47, 311-326.

11. Chen, F., Zhong, F., \& Chen, Y. (2014). Outward foreign direct investment and sovereign risks in developing host countries. Economic Modelling, 41, 166-172.

12. Claudia M. B. \& Alexander, L. (2005). Business Cycles and FDI: Evidence from German Sectoral DataKiel Institute for World Economics DOI: 10.1007/s10290-005-0053-5

13. Dar, A. A., Bhatti, H. M. A., \& Muhammad, T. (2016). FDI and Economic Growth in Pakistan: A Sector Wise Multivariate Cointegration Analysis. The Pakistan Development Review, 67-88.

14. Daude, C. \& Stein, E. (2008). The quality of institutions and foreign direct investment. Economics \& Politics, 19(3), 317-344.

15. Demir, F. \& Duan, Y. (2018). Bilateral FDI flows, productivity growth, and convergence: The north vs. The south. World Development, 101, 235-249.

16. Dickey, D.A. \& Fuller, W.A. (1981). "Distribution of the Estimators for Autoregressive Time Series with a Unit Root", Econometrica 49: 1057-1072.

17. Donou-Adonsou, F. \& Lim, S. (2018). On the importance of Chinese investment in Africa. Review of development finance, 8(1), 63-73.

18. Economou, F. (2019). Economic freedom and asymmetric crisis effects on FDI inflows: The case of four South European economies. Research in International Business and Finance, 49, ''114-126.

19. Fan, H., Lin, F., \& Tang, L. (2018). Minimum wage and outward FDI from China. Journal of Development Economics, 135, 1-19.

20. Gao, L., Liu, X., \& Zou, H. (2013). The role of human mobility in promoting Chinese outward FDI: A neglected factor?. International Business Review, 22(2), 437-449.

21. Ghironi, F. \& M. J. Melitz (2004). International Trade and Macroeconomic Dynamics with 7. Heterogeneous Firms. NBER Working Paper 10540. National Bureau of Economic Research, Cambridge, Mass.

22. Gnangnon, S. K. (2018). Effect of multilateral trade liberalization on foreign direct investment outflows amid structural economic vulnerability in developing countries. Research in International Business and Finance, 45, 15-29.

23. Gossel, S. J. (2018). FDI, democracy, and corruption in Sub-Saharan Africa. Journal of Policy Modeling, 40(4), 647-662. 
24. Gusarova, S. (2019). Role of China in the development of trade and FDI cooperation with BRICS countries. China Economic Review, 57, 101271.

25. Habyarimana, J. B. \& Opoku, E. E. O. (2018). Technological progress, worker efficiency, and growth in Africa: Does China's economy matter?. China Economic Review, 52, 151-164.

26. Hansen H. \& Rand, J. (2006). On the causal links between FDI and growth in developing countries. The World Economy, 29, 1, 21.

27. Iyer, T. \& Gupta, A. S. (2019). Quarterly Forecasting Model for India's Economic Growth: Bayesian Vector Autoregression Approach. Asian Development Bank Economics Working Paper Series, (573).

28. Jibir, A. \& Abdu, M. (2017). Foreign Direct Investment-Growth Nexus: The Case of Nigeria.

29. Karimi, Mohammad Sharif, and Yusop, Zulkornain(2009). FDI and Economic Growth in Malaysia.

30. Kayalvizhi, P. N. \& Thenmozhi, M. (2018). Does the quality of innovation, culture, and governance drive FDI?: Evidence from emerging markets. Emerging Markets Review, 34, 175-191.

31. Kottaridi, C., Louloudi, K., \& Karkalakos, S. (2019). Human capital, skills, and competencies: Varying effects on inward FDI in the EU context. International Business Review, 28(2), 375-390.

32. Krasniqi, S. \& Krasniqi, E. H. (2015). Pristina's development strategy of 2013-2016: An analysis of the situation in the educational, cultural, youth, and sports sectors. European Scientific Journal, 11(19).

33. Kukaj, H. \& Ahmeti, F. B. (2016). The Importance Of Foreign Direct Investments On Economic Development In Transitional Countries: A Case Study Of Kosovo. European Scientific Journal, 12(7).

34. Latorre, M. C., Yonezawa, H., \& Zhou, J. (2018). A general equilibrium analysis of FDI growth in Chinese services sectors. China Economic Review, 47, 172-188.

35. Le, T. H. \& Tran-Nam, B. (2018). Relative costs and FDI: Why did Vietnam forge so far ahead?. Economic Analysis and Policy, 59, 1-13.

36. Liu, X., Buck, T., \& Shu, C. (2005). Chinese economic development, the next stage: outward FDI?. International Business Review, 14(1), 97-115.

37. Mahmoud, L. O. M. (2015). Consumer price index and economic growth: a case study of Mauritania 1990-2013. Asian Journal of Empirical Research, 5(2), 16-23.

38. Mourao, P. R. (2018). What is China seeking from Africa? An analysis of the economic and political determinants of Chinese Outward 
Foreign Direct Investment based on Stochastic Frontier Models. China Economic Review, 48, 258-268.

39. Mukhtar, T., Jehan, Z., \& Bilquees, F. (2019). Is Trade Openness Inflationary in Developing Economies: An Asymmetric Analysis for Pakistan. Pakistan Economic and Social Review, 57(1), 47.

40. Nguyen, C. P., Schinckus, C., Su, T. D., \& Chong, F. (2018). Institutions, inward foreign direct investment, trade openness, and credit level in emerging market economies. Review of development finance, 8(2), 75-88.

41. Nizam, H. A., Zaman, K., Khan, K. B., Batool, R., Khurshid, M. A., Shoukry, A. M., ... \& Gani, S. (2020). Achieving environmental sustainability through information technology: "Digital Pakistan" initiative for green development. Environmental Science and Pollution Research, 1-16.

42. Nyangarika, A., Mikhaylov, A., \& Richter, U. (2019). Influence oil price towards economic indicators in Russia. International Journal of Energy Economics and Policy, 1(6), 123-130.

43. Oxelheim, L. \& Ghauri, P. (2008). EU-China and the non-transparent race for inward FDI. Journal of Asian Economics, 19(4), 358-370.

44. Pesaran, M. H., Shin, Y., \& Smith, R. J. (2001). Bounds testing approaches to the analysis of level relationships. Journal of applied econometrics, 16(3), 289-326.

45. Piperopoulos, P., Wu, J., \& Wang, C. (2018). Outward FDI, location choices, and innovation performance of emerging market enterprises. Research Policy, 47(1), 232-240.

46. Rafindadi, A. A., Muye, I. M., \& Kaita, R. A. (2018). The effects of FDI and energy consumption on environmental pollution in predominantly resource-based economies of the GCC. Sustainable Energy Technologies and Assessments, 25, 126-137.

47. Rahman, Z. U. \& Ahmad, M. (2019). Modeling the relationship between gross capital formation and $\mathrm{CO} 2$ (a) symmetrically in the case of Pakistan: an empirical analysis through the NARDL approach. Environmental Science and Pollution Research,26(8), 8111-8124.

48. Rehman, N., Khurshid, M. K., \& Saleem, A. (2019). Financial and Economic Indicators of Economic Advancement: Evidence from Asian Countries. International Transaction Journal of Engineering, Management, \& Applied Sciences \& Technologies, 10(11), 1-15.

49. Sayari, N., Sari, R., \& Hammoudeh, S. (2018). The impact of valueadded components of GDP and FDI on economic freedom in Europe. Economic Systems, 42(2), 282-294. 
50. Shah, S. H., Hasnat, H., Cottrell, S., \& Ahmad, M. H. (2019). Sectoral FDI inflows and domestic investments in Pakistan. Journal of Policy Modeling.

51. Shahbaz, M., Nasir, M. A., \& Roubaud, D. (2018). Environmental degradation in France: the effects of FDI, financial development, and energy innovations. Energy Economics, 74, 843-857.

52. Shaqiri, J. (2017). The Impact of Export and Foreign Direct Investments on Macedonian GDP Growth-Empirical Analysis. European Scientific Journal, 13(25), 276-287.

53. Shi, J. (2019). Vertical FDI and exchange rates over the business cycle: the welfare implications of openness to FDI. Journal of Development Economics, 138, 274-293.

54. Stanojević, N. (2019). The Impact of Chinese Infrastructure Projects on Development of Host Economies. The Review of International Affairs, 70(1173), 201961.

55. Stein, E. \& Daude, C. (2001). Institutions, integration, and the location of foreign direct investment. New Horizons for Foreign Direct Investment, 101-28

56. Sun, S. \& Anwar, S. (2019). R\&D activities and FDI in China's iron ore mining industry. Economic Analysis and Policy, 62, 47-56.

57. Tolentino, P. E. (2010). Home country macroeconomic factors and outward FDI of China and India. Journal of International Management, 16(2), 102-120.

58. Uddin, M., Chowdhury, A., Zafar, S., Shafique, S., \& Liu, J. (2019). Institutional determinants of inward FDI: Evidence from Pakistan. International Business Review, 28(2), 344-358.

59. UNCTAD (2016). World investment report 2016: Investor nationality: Policy challenges, UNCTAD (United Nations Conference on Trade and Development)), Geneva., 2016.

60. Yang, J. H., Wang, W., Wang, K. L., \& Yeh, C. Y. (2018). Capital intensity, natural resources, and institutional risk preferences in Chinese Outward Foreign Direct Investment. International Review of Economics \& Finance, 55, 259-272.

61. Yang, S. F., Chen, K. M., \& Huang, T. H. (2013). Outward foreign direct investment and technical efficiency: Evidence from Taiwan's manufacturing firms. Journal of Asian Economics, 27, 7-17.

62. Yusuf, S. (2013). Can Chinese FDI Accelerate Pakistan's Growth?. International Growth Centre, 4.

63. Zefi, E. \& Pasholli, A. (2011). The energy of Albanian and foreign investments with impacts on overpassing the global crisis effects. European Scientific Journal, 43. 